appointments, he joined the Standard Oil Co. (N.J.), in 1927, when he became research director of the newly established Esso Laboratories at Baton Rouge, La. Here he initiated research on the hydrogenation process and the manufacture of synthetic products from petroleum. Mr. Russell is now directing research on new and improved uses for crude oil, the production of liquid fuels from coal and natural gas, and the development of improved synthetic rubbers and plasties.

\section{Institution of Electrical Engineers :} Honorary Member

THE Council of the Institution of Electrical Engineers has elected Sir John Macfarlane Kennedy, past president, to be an honorary member of the Institution, in recognition of his distinguished work in the sphere of electricity supply and of the services rendered by him to the Institution. Sir John was at Trinity College, Cambridge, and also went to Zurich Polytechnic. $\mathrm{He}$ served his pupillage with Richard Moreland and Sons, London, Willans and Robinson, Rugby, and Siemens-Halske, Berlin. During 1902-34 he was a partner in the firm of Kennedy and Donkin, and was engaged in electricity supply, distribution and traction works. In 1922 he submitted to the Electricity Commissioners proposals for the reorganisation of electricity supply in Great Britain, and eventually prepared a report for the Ministry of Transport on the reorganisation of electricity supply. In 1934 he took office with the Electricity Commission, of which he is now deputy-chairman.

Faraday Medal

THE Faraday Medal of the Institution has been awarded to Sir Standen Leonard Pearce, for his outstanding contributions to the advancement of engineering practice and notable achievements in electrical engineering. Sir Leonard Pearce was educated at Bishops Stortford College and Finsbury Technical College, London. He served his pupillage with J. G. Statter and Co. at West Drayton, and Thomas Richardson and Sons of Hartlepool. After occupying various posts, he was appointed in 1903 to be chief engineer to Manchester Corporation Electricity Undertaking; in 1926 he became engineer-in-chief of the London Power Co.

\section{Prof. F. J. W. Roughton, F.R.S.}

Dr. F. J. W. Roughton, who succeeds Prof. E. K. Rideal in the John Humphrey Plummer professor. ship of colloid science in the University of Cambridge, is a physiologist admirably qualified to deal with the border-line between biological and physical science. Since his election to a fellowship at Trinity College, Cambridge, in 1923, his researches have been concerned with the carriage of gases by the blood and with the physical chemistry of the blood pigments. His best-known work is that begun with Meldrum on the enzyme carbonic anhydrase, which plays an important part in the transport of carbon dioxide from the tissues to the lungs. Physical chemists will remember also the ingenious methods which he used with Hartridge to study the rapid rate of combination of oxygen with hæmoglobin. Largely as the result of his work, the complex interchanges between the corpuscles and the plasma in the lung capillaries are far more clearly understood. His wide knowledge of physico-chemical techniques and of their application to biological problems has made him an authority in a field which is rapidly becoming one of the growing points in natural science; and physiologists will wish him every success in an appointment which will give full scope to his talent for reducing biological equations to measurable terms.

\section{Human Nutrition at the London School of Hygiene and Tropical Medicine: Prof. B. S. Platt, C.M.G.}

THE increasing importance attached to the scientific study of nutrition is reflected in the appointment of Dr. B. S. Platt as professor of human nutrition at the London School of Hygiene and Tropical Medicine. Dr. Platt will continue to hold, in conjunction with the chair, his present post as director of the Medical Research Council's Research Unit of Human Nutrition, at the National Hospital, Queen Square, London. His appointment is thus also another welcome sign of the growing readiness of universities to elect to professorial rank those whose duties are primarily in research; under the old system a professor was too often so fully occupied with teaching as to have little time left for research. Dr. Platt graduated in the School of Chemistry at Leeds in 1923. He engaged in research there under the late Prof. J. B. Cohen, was elected to a Beit Memorial Fellowship in 1926, and became medically qualified in 1930. During 1932-38 he was attached to the Division of Clinical Research of the Henry Lester Institute of Medical Research at Shanghai, as associate in medicine, and in 1932 was the author of the B.M.A. "Bishop Harman Prize Essay" on "The Importance of Vitamin $B_{1}$ for Maternal Health in Pregnancy and Lactation". In 1938 he was appointed to the scientific staff of the Medical Research Council, and since 1944 has been director' of the Council's Human Nutrition Research Unit.

Dr. Platt has served as a nutritional expert on a considerable number of government committees, including the Scientific Food Policy Committee, the Committee for the Care of Shipwrecked Personnel, the Rations Sub-committee of the Military Personnel Research Committee, and the United Kingdom Delegation to the Food and Agriculture Organisation Conferences ; and in his work he has travelled widely, including visits to West and East African territories, Newfoundland and the West Indies. In 1944, he gave the De Lamar Lecture in hygiene at the Johns Hopkins University. He has published a considerable number of papers, dealing mostly with biochemical studies on water-soluble vitamins, his best known work perhaps being that with Miss Lu on the blood pyruvate in vitamin $B_{1}$ deficiency in man.

\section{Prof. Frank Horton, F.R.S.}

THE recent retirement of Prof. Frank Horton from the University chair of physics which he has held at. the Royal Holloway College (University of London) since 1914 brings to an end an active teaching career lasting more than forty years. That career really falls into two parts, Cambridge and London, though it should be mentioned that he received his earlier training at Birmingham, of which University he holds the degree of M.Sc. At Cambridge, as a lecturer at the Cavendish Laboratory in the days of $\mathrm{J}$. $\mathrm{J}$. Thomson, he formed one of that brilliant team of young physicists comparable in their way with those other teams in other spheres during the same epoch, namely, 'Cromer's young men'in Egypt and the Sudan, and 'Milner's young men' in South Africa. An early 